\title{
MENGHITUNG WAKTU PANEN TANAMAN BAWANG MERAH BERBASIS HEAT UNIT PADA PEMBERIAN PUPUK ORGANIK DI TANAH GAMBUT
}

\author{
(Calculating the Harvest Time of Onion Plant Based on Unit of Heat on Giving \\ the Organic Fertilizer in Peat Soil)

\section{DJOKO EKO HADI SUSILO}

\author{
Program Studi Agroteknologi Fakultas Pertanian dan Kehutanan \\ Universitas Muhammadiyah Palangkaraya \\ JI. RTA Milono Km.1,5 Palangka Raya, Kalimantan Tengah 73111 \\ e-mail : masdjoko_ns@yahoo.co.id
}

\begin{abstract}
Determining of the harvest of onion in the peat soil can be done by using physiological harvest criteria, but calculating the appropriate of harvest time can support the quality of harvesting of onion plant. This study aims to calculate the harvest time of onion plant based on unit of heat (heat units) as a result of giving organic fertilizer in peat soil.

This study was conducted by using polybags in research and experiment gardens of the Faculty of Agriculture and Forestry of the University of Muhammadiyah Palangkaraya in April to June in 2016. The given fertilization was an organic fertilizer in peat soil by using stall fertilizer like chicken feces with dosages of 15-30 tons ha ${ }^{-1}$ (PK) and bokashi of stall fertilizer of chicken feces with dosage of 2-5 tons ha ${ }^{-1}$ (BK). The observation done to the calculation of daily temperature $\left({ }^{\circ} \mathrm{C}\right)$, the average of daily temperature $\left({ }^{\circ} \mathrm{C}\right)$, and the unit of heat (heat unit) ${ }^{\circ} \mathrm{C}$ day) as long as the cultivation of onion plant. The observation time of harvest based on physiological criteria, namely the PK treatment of harvest time at the age of 59 days after planting and the BK treatment of harvest time at the age of 57 days after planting.

The results showed that the harvest time that appropriate to the harvest physiological criteria in the treatment of $B K$ at the age of 57 days after planting is relatively accurate and appropriate because it has a heat unit for $947,17^{\circ} \mathrm{C}$ day, and the harvest time that appropriate to the harvest physiological criteria of PK treatment at the age of 59 days after planting is relatively late because it has a heat unit for $978,09^{\circ} \mathrm{C}$ day, because harvest of onion Super Philip has a heat unit for $945,8^{\circ} \mathrm{C}$ day. The results also suggest a further studies to determine the harvest time of onion based on calculating unit of heat in cultivation in some of the cultivating season in peat soil.
\end{abstract}

Keywords: harvest time, heat unit, onion, organic fertilizer, peat soil

\begin{abstract}
ABSTRAK
Penentuan panen tanaman bawang merah di tanah gambut bisa dilakukan menggunakan kriteria panen fisiologis, tetapi menghitung waktu panen yang tepat dapat mendukung kualitas panen tanaman bawang merah. Penelitian ini bertujuan untuk menghitung waktu panen tanaman bawang merah yang berbasis satuan panas (heat unit) akibat pemberian pupuk organik di tanah gambut.

Penelitian ini dilaksanakan menggunakan polybag di Kebun Penelitian dan Percobaan (KP2) Fakultas Pertanian dan Kehutanan Universitas Muhammadiyah Palangkaraya pada bulan April sampai Juni 2016. Pemupukan yang diberikan adalah pupuk organik di tanah gambut menggunakan pupuk kandang kotoran ayam dosis $15-30$ ton ha ${ }^{-1}$ (PK) dan bokashi pupuk kandang kotoran ayam dosis $2-5$ ton ha ${ }^{-1}(B K)$. Pengamatan dilakukan terhadap hitungan suhu harian $\left({ }^{\circ} \mathrm{C}\right)$, rata-rata suhu harian $\left({ }^{\circ} \mathrm{C}\right)$, dan satuan panas (heat unit) $\left({ }^{\circ} \mathrm{C}\right.$ hari) selama budidaya tanaman bawang merah. Pengamatan waktu panen dilakukan berdasarkan kriteria fisiologis yaitu perlakuan PK waktu panen pada umur 59 hari setelah tanam (HST) dan pada perlakuan BK waktu panen pada umur 57 hari setelah tanam (HST).

Hasil penelitian menunjukkan bahwa waktu panen sesuai kriteria panen fisiologis pada perlakuan BK pada umur 57 HST adalah relatif tepat dan sesuai karena memiliki heat unit sebesar $947,17^{\circ} \mathrm{C}$ hari, dan waktu panen sesuai kriteria panen fisiologis pada perlakuan PK pada umur 59 HST adalah relatif terlambat yang memiliki heat unit sebesar $978,09^{\circ} \mathrm{C}$ hari karena panen bawang merah varietas Super Philip memiliki heat unit sebesar $945,8^{\circ} \mathrm{C}$ hari. Hasil penelitian juga menyarankan penelitian lanjutan untuk penentuan waktu panen tanaman bawang merah berdasarkan penghitungan heat unit pada budidaya di beberapa musim tanam di tanah gambut.
\end{abstract}

Kata kunci : waktu panen, heat unit, bawang merah, pupuk organik, tanah gambut 


\section{PENDAHULUAN}

Komoditas hortikultura unggulan salah satunya adalah bawang merah (Allium ascalonicum). Fakta sebagai salah satu komoditas unggulan yaitu termasuk yang sering dibutuhkan dan dikonsumsi setiap harin. Meningkatnya jumlah penduduk menjadikan kebutuhan bawang merah sehari-hari juga menjadi bertambah banyak sebagai bumbu penyedap rasa secara segar maupun bahan baku industri bumbu.

Masyarakat di Palangka Raya dan Kalimantan Tengah membutuhkan komoditas hortikultura berupa bawang merah digunakan sebagai bumbu masakan maupun sebagai obat tradisional setiap harinya dalam jumlah yang banyak. Oleh karena itu dibutuhkan budidaya dengan produksi yang banyak pula. Berbagai upaya budidaya bawang merah terkadang menghasilkan produksi yang rendah, terjadi gagal panen, gangguan hama dan penyakit atau gangguan pasca panen bisa memicu terjadinya kelangkaan bawang merah sehingga dampaknya harga bawang merah menjadi meningkat di pasar. Hal ini membutuhkan upaya untuk pemenuhan kebutuhan bawang merah di Kalimantan Tengah yaitu dengan produksi yang tinggi dengan kualitas panen yang baik juga.

Produksi bawang merah di Kalimantan Tengah pada Tahun 2014 sebesar 125 ton dengan luasan panen sebesar 55 ha sehingga produktivitasnya sebesar 2,27 ton ha ${ }^{-1}$. Kegiatan penanaman bawang merah untuk memenuhi kebutuhan di Kalimantan Tengah dan khususnya di Palangka Raya sudah dimulai pada tahun 2012 (BPS, 2015).
Budidaya tanaman bawang merah menjadi menarik karena banyak dibutuhkan, umur panen yang relatif singkat, dapat tumbuh dengan baik di dataran rendah, meskipun juga ada kendala produktivitas diantaranya jenis tanah pada lahan, kondisi kesuburan lahan, hama dan penyakit tanaman, ketepatan saat panen, dan pengelolaan pasca panen yang tepat. Hal ini membutuhkan perbaikan budidaya dan upaya panen serta pasca panen yang baik.

Kendala pengembangan budidaya tanaman bawang merah pertanian di lahan gambut diantaranya bisa diperbaiki dengan peningkatan kesuburan tanahnya menggunakan pupuk organik berupa pupuk kandang kotoran ayam secara langsung (Nurani, 2016) maupun diberikan pupuk kandang kotoran ayam yang dijadikan bokashi diberi aktivator mikroorganisme terlebih dulu (Safrudin, 2016). Untuk melengkapi upaya produksi bawang merah yang tinggi, selain melakukan budidaya yang maka diperlukan juga penentuan waktu panen yang tepat dan pengelolaan pasca panen yang tetap menjaga mutu hasil panen.

Segala aspek budidaya tanaman bawang merah di lahan sesungguhnya semua menjadi penting, namun produksi yang tinggi tidak ditindaklanjuti dengan panen dan pasca panen yang baik akhirnya menurunkan kondisi pemenuhan kebutuhan bawang merah secara menyeluruh. Oleh karena itu, beberapa hal yang menjadi perhatian penting dalam budidaya bawang merah adalah menyangkut masalah kuantitas dan kualitas hasil panen bawang merah tersebut. 
Permasalahan kuantitas bawang merah yang rendah (produksi maupun produktivitasnya) bisa disebabkan oleh kurangnya optimalisasi penggunaan lahan, namun permasalahan kualitas bawang merah yang rendah salah satunya juga termasuk disebabkan oleh penentuan waktu panen yang kurang tepat.

Penentuan waktu panen bawang merah yang kurang tepat umumnya karena petani menetapkan umur panen bawang merah berdasarkan kriteria fisiologis dan berpedoman pada satuan hari, tetapi cara ini kurang sesuai untuk dijadikan pegangan karena umur suatu genotip tanaman berbeda-beda tergantung dari faktor lingkungan tumbuh. Oleh karena itu, fase pertumbuhan berbagai tanaman maupun penentuan waktu panen yang kurang tepat dapat didekati dengan konsep perhitungan heat unit, termasuk untuk tanaman bawang merah. Kondisi ini sebagaimana telah dilakukan oleh Soelistyono (2010) bahwa pengamatan suhu udara sebaiknya dimanfaatkan untuk menentukan suhu dasar pertumbuhan beberapa jenis tanaman. Begitu juga Kamillah (2006) menjelaskan bahwa pengamatan suhu harian sebaiknya dilanjutkan pengolahan data suhunya untuk menghitung jumlah panas (heat sum) yang dapat digunakan menaksir saat berbunga maupun saat panen tanaman budidaya.

Oleh karena itu, penentuan waktu panen bawang merah yang kurang tepat dapat didekati dengan konsep perhitungan heat unit yaitu konsep yang dikembangkan atas dasar bahwa tanaman budidaya setiap harinya mengumpulkan sejumlah satuan panas yang besarnya tergantung suhu rata-rata harian yang mempengaruhi pertumbuhan tanaman dan besaran masing- masing suhu dasar yang dimiliki masing-masing tanaman sehingga dapat diketahui suhu dasar dan suhu harian yang dimiliki tanaman tersebut berpengaruh terhadap pertumbuhan dan hasil tanaman saat dibudidayakan (Yaqin et al., 2015).

Berdasarkan beberapa hal pada latar belakang tersebut, maka dalam budidaya tanaman bawang merah diperlukan pengamatan suhu harian dengan harapan dapat ditentukan konsep heat unit yang dimiliki sehingga mendapatkan kuantitas produksi yang tinggi, kemudian dilengkapi dengan pendekatan penentuan waktu panen yang tepat. Hal ini dilakukan sebagai upaya memenuhi kebutuhan bawang merah bagi masyarakat dari segi kuantitas yang tinggi dan dukungan kualitas hasil panen yang baik.

Berdasarkan gambaran betapa pentingnya produksi dan kualitas hasil tanaman bawang merah tersebut, maka penelitian ini memiliki tujuan untuk : 1). menghitung nilai satuan panas (heat unit) tanaman bawang merah akibat pemberian pupuk organik di tanah gambut, dan 2). mendapatkan waktu panen tanaman bawang merah yang berkualitas berbasis heat unit akibat pemberian pupuk organik di tanah gambut.

\section{METODOLOGI}

Penelitian ini dilaksanakan dengan melakukan percobaan budidaya tanaman bawang merah menggunakan polybag di Kebun Penelitian dan Percobaan (KP2) Fakultas Pertanian dan Kehutanan Universitas Muhammadiyah Palangkaraya, dengan lokasi di Jl. Anggrek, Kelurahan Kereng Bangkirai, Kecamatan Sabangau Kota Palangka Raya, selama 3 (tiga) bulan yaitu pada bulan April-Juni 2016. 
Bahan-bahan yang digunakan adalah, bawang merah varietas Super Philip, pupuk organik (pupuk kandang kotoran ayam), EM4, sekam, gula, air, kapur dolomit. Peralatan yang digunakan adalah cangkul, sekop, karung, ember, gembor, polybag dengan ukuran $30 \times 35 \mathrm{~cm}$, neraca analitik, thermometer, kamera, kalkulator, alat tulis, dan komputer.

Rancangan lingkungan yang digunakan pada penelitian ini adalah Rancangan Acak Lengkap (Mattjik dan Sumertajaya, 2002) dengan perlakuan pupuk kandang kotoran ayam (PK) yang diberikan langsung sebagai pupuk dasar dengan dosis mencapai $15-30$ ton ha $^{-1}$ dan perlakuan bokashi pupuk kandang kotoran ayam (BK) yang diberikan langsung sebagai pupuk dasar dengan dosis mencapai 2-5 ton ha ${ }^{-1}$.

Selama percobaan, di lokasi budidaya dipasang thermometer yang digunakan untuk mengukur suhu maksimum dan minimum harian. Data suhu diamati dan dicatat setiap hari mulai saat tanam hingga panen. Berdasarkan data suhu harian maka dapat dihitung dan ditentukan jumlah satuan panas (heat unit) yang dibutuhkan waktu panen tanaman bawang merah sekaligus memberikan gambaran waktu yang tepat untuk panen tanaman bawang merah.

Suhu maksimum $\left(T_{\text {mak }}\right)$ adalah suhu tertinggi selama periode 24 jam, sedangkan suhu minimum $\left(T_{\min }\right)$ adalah suhu terendah yang tercatat selama periode 24 jam. Suhu rata-rata $\bar{T}$ adalah rata-rata dari suhu maksimum dan minimum selama periode 24 jam. Satuan panas dihitung dengan menggunakan persamaan Ney and Turc (1993 dalam Polii, 2003) yaitu :

$$
S P_{0}=\sum_{i=1}^{n}(\bar{T}-T b)
$$

yaitu :

$S P_{0}:$ satuan panas $\left({ }^{\circ} \mathrm{C}\right.$ hari);

$i$ : hari mulai tanam sampai periode perkembangan tertentu (dimana $\mathrm{i}=1$, $2,3,4, \ldots, n)$;

$n \quad: \quad$ hari sesudah tanam (hari);

$\bar{T} \quad$ : suhu rata-rata harian atau hari ke-i $\left({ }^{\circ} \mathrm{C}\right)$;

$\mathrm{Tb}$ : suhu dasar fisiologis tanaman $\left({ }^{\circ} \mathrm{C}\right)$.

Suhu rata-rata dihitung atas data suhu maksimum dan minimum harian dengan rumus menurut Ney and Turc (1993 dalam Polii, 2003) yaitu :

$$
T=\left(\underline{T}_{\frac{\operatorname{mak}}{2}+T_{\min }}\right)
$$

yaitu :

$T$ = rata-rata dari suhu maksimum dan minimum $\left({ }^{\circ} \mathrm{C}\right)$;

$T_{\text {mak }}=$ suhu maksimum/tertinggi selama periode 24 jam $\left({ }^{\circ} \mathrm{C}\right)$;

$T_{\min }=$ suhu minimum/terendah selama periode 24 jam $\left({ }^{\circ} \mathrm{C}\right)$.

Rumus perhitungan heat unit untuk tanaman bawang merah adalah sebagai berikut :

$S P=\Sigma\left(\bar{T}-T_{b}\right)$

yaitu :

$S P=$ heat unit (satuan panas) yang diperlukan tanaman bawang merah untuk mencapai suatu fase perkembangan tertentu $\left({ }^{\circ} \mathrm{C}\right.$ hari).

$\bar{T}$ = suhu udara rata-rata harian di sekitar tanaman bawang merah, diukur selama pengamatan $\left({ }^{\circ} \mathrm{C}\right)$.

$T_{b}=$ suhu dasar fisiologis tanaman bawang merah, ditentukan untuk tanaman bawang merah yaitu $11,4^{\circ} \mathrm{C}$ (Soelistyono, 2010).

Pelaksanaan panen tanaman bawang merah mengacu pada kriteria panen fisiologis yaitu daun tanaman sudah mulai layu, daun telah menguning $70-80 \%$ dari jumlah tanaman, pangkal batang mengeras, sebagian umbi telah keluar di atas tanah, lapisan umbi yang muncul ke 
permukaan tanah berwarna merah. Atas dasar kriteria panen tersebut, akibat perlakuan pupuk organik (pupuk kandang kotoran ayam = PK) dipanen pada waktu tanaman bawang merah berumur mulai 59 hari setelah tanam (HST) dan akibat perlakuan pupuk organik (bokashi pupuk kandang kotoran ayam $=$ BK) dipanen pada waktu tanaman bawang merah berumur 57 hari setelah tanam (HST).

\section{HASIL DAN PEMBAHASAN}

\section{Hasil Pengamatan Waktu Panen dan Perhitungan Heat Unit}

Hasil pengamatan pertumbuhan dan waktu panen dengan berdasarkan kriteria fisiologis tanaman bawang merah varietas Super Philip dilakukan secara berdampingan dengan pengamatan suhu dan satuan panas (heat unit) sehari-harinya. Heat unit yang telah diamati dan dihitung sebagai penentuan waktu panen pada tanaman bawang merah varietas Super Philip yang dibudidayakan di tanah gambut Kota Palangka Raya akibat pemberian pupuk organik disajikan pada Tabel 1.

Memperhatikan waktu panen tanaman bawang merah, ternyata tanaman bawang merah dapat dipanen pada umur 55-60 hari setelah tanam apabila ditanam di dataran rendah (Baswarsiati, 2009). Apabila memperhatikan potensi waktu panen tersebut, maka sejak umur 56 hari setalah tanam perlu dilakukan perhitungan besaran satuan panas (heat unit) untuk menggambarkan informasi kapan waktu panen yang bisa dilakukan.

Berdasarkan pengamatan suhu harian, hasil rekapitulasi perhitungan satuan panas (heat unit) pada budidaya tanaman bawang merah varietas Super Philip di tanah gambut Kota Palangka Raya yang dipupuk menggunakan pupuk organik (pupuk kandang kotoran ayam) disajikan pada Tabel 2.

Tabel 1. Kondisi perbedaan penentuan waktu panen tanaman bawang merah varietas Super Philip di tanah gambut Kota Palangka Raya akibat pemberian pupuk organik menurut kriteria panen fisiologis dan berbasis perhitungan heat unit

\begin{tabular}{|c|c|c|c|}
\hline \multirow[b]{2}{*}{ Perlakauan Pupuk Organik } & \multirow{2}{*}{$\begin{array}{c}\text { Waktu Panen } \\
\text { Berdasarkan Kriteria } \\
\text { Fisiologis (hari)*) }\end{array}$} & \multicolumn{2}{|c|}{ Waktu Panen Berbasis Heat Unit } \\
\hline & & $\begin{array}{l}\text { Heat Unit } \\
\left({ }^{\circ} \mathrm{C} \text { hari) }\right.\end{array}$ & $\begin{array}{c}\text { Waktu Panen } \\
\text { yang Tepat (hari) }\end{array}$ \\
\hline \multicolumn{4}{|l|}{ Pupuk Kandang Kotoran Ayam } \\
\hline PK $\left(15\right.$ ton ha $\left.{ }^{-1}\right)$ & 60 & 993,44 & 57 \\
\hline PK (20 ton ha $\left.{ }^{-1}\right)$ & 60 & 993,44 & 57 \\
\hline PK (25 ton ha $\left.{ }^{-1}\right)$ & 59 & 978,09 & 57 \\
\hline PK (30 ton ha $\left.{ }^{-1}\right)$ & 59 & 978,09 & 57 \\
\hline \multicolumn{4}{|c|}{ Bokashi Pupuk Kandang Kotoran Ayam : } \\
\hline $\mathrm{BK}\left(2\right.$ ton $\left.\mathrm{ha}^{-1}\right)$ & 60 & 993,44 & 57 \\
\hline $\mathrm{BK}\left(3\right.$ ton ha $\left.{ }^{-1}\right)$ & 57 & 947,17 & 57 \\
\hline $\mathrm{BK}\left(4\right.$ ton ha $\left.{ }^{-1}\right)$ & 57 & 947,17 & 57 \\
\hline $\mathrm{BK}\left(5\right.$ ton $\left.\mathrm{ha}^{-1}\right)$ & 57 & 947,17 & 57 \\
\hline
\end{tabular}

Keterangan : *) berdasarkan Safrudin (2016) dan Nurani (2016) 
Tabel 2. Rekapitulasi perhitungan heat unit pada budidaya tanaman bawang merah varietas Super Philip di tanah gambut Kota Palangka Raya akibat pemberian pupuk organik

\begin{tabular}{ccll}
\hline $\begin{array}{c}\text { Umur Tanaman } \\
\text { Bawang Merah (hari) }\end{array}$ & $\begin{array}{c}\text { Hitungan } \\
\text { Heat Unit }\left({ }^{\circ} \mathbf{C} \text { hari) }\right.\end{array}$ & $\begin{array}{c}\text { Waktu Panen Berbasis } \\
\text { Heat Unit }\end{array}$ & $\begin{array}{c}\text { Waktu Panen Berbasis } \\
\text { Kriteria Fisiologis }\end{array}$ \\
\hline 55 & 914,07 & Belum sesuai waktu panen & Belum sesuai kriteria panen \\
56 & 931,29 & Belum sesuai waktu panen & Belum sesuai kriteria panen \\
$\mathbf{5 7}$ & $\mathbf{9 4 7 , 1 4}$ & Sesuai waktu panen & Sesuai kriteria panen \\
58 & 960,74 & Lambat sesuai waktu panen & Sesuai kriteria panen \\
59 & 978,09 & Lambat sesuai waktu panen & Sesuai kriteria panen \\
60 & 993,44 & Lambat sesuai waktu panen & Sesuai kriteria panen \\
\hline
\end{tabular}

\section{Pembahasan}

Budidaya tanaman hortikultura selain berupaya meningkatkan nilai produksi juga meningkatkan kualitas hasil panen sehingga dalam setiap budidaya tanaman hortikultura tersebut maka selalu melewati waktu panen di lapangan. Berkaitan dengan panen, maka dibutuhkan penentuan waktu panen yang tepat dan bisa dilakukan melalui berbagai pendekatan. Wahyono et al. (2013) menjelaskan bahwa panen yang dilakukan saat budidaya bisa didasarkan atas pendekatan umur, ciri tanaman dan prediksi cuaca, namun semuanya berdasarkan pengalaman di lapangan berupa hasil pengamatan.

Heat unit yang dibutuhkan sebagai saat panen yang tepat pada tanaman bawang merah di dataran rendah ternyata berbeda, dan salah satunya bergantung dari jenis atau varietasnya. Tanaman bawang merah varietas Bauji membutuhkan sekitar $945,8^{\circ} \mathrm{C}$ hari, varietas Super Philip juga membutuhkan sekitar $945,8^{\circ} \mathrm{C}$ hari, dan varietas Batu ljo membutuhkan sekitar $1.173^{\circ} \mathrm{C}$ hari yang dibudidayakan di Desa Lengkong Kecamatan Lengkong Kabupaten Nganjuk Jawa Timur dengan ketinggian tempat sekitar $43 \mathrm{~m}$ dpl dan memiliki suhu rata-rata harian sekitar $30^{\circ} \mathrm{C}$ saat dibudidayakan (Yaqin dkk., 2015).

Berdasarkan Tabel 1, nampak terlihat bahwa akibat pemberian pupuk organik berupa pupuk kandang kotoran ayam secara langsung memberikan pertumbuhan tanaman bawang merah yang bervariasi sehingga menampilkan waktu kriteria fisiologis yang beragam, yaitu mulai pada umur 59 dan 60 hari setelah tanam. Apabila ditinjau dari perhitungan heat unit, maka pada umur tanaman bawang merah varietas Super Philip tersebut memiliki heat unit berturut-turut sebesar 978,09 dan $993,44^{\circ} \mathrm{C}$ hari. Hal ini membuktikan bahwa mengikuti waktu panen dengan memperhatikan kriteria fisiologisnya menjadi lambat beberapa hari, karena jumlah heat unit yang paling mendekati kebutuhannya adalah pada heat unit sebesar $947,17^{\circ} \mathrm{C}$ hari yaitu pada umur 57 hari setelah tanam.

Berdasarkan Tabel 1 juga terlihat bahwa akibat pemberian pupuk organik berupa pupuk kandang kotoran ayam yang diolah terlebih dulu menjadi menjadi bokashi (BK) memberikan dukungan pertumbuhan tanaman bawang merah yang bervariasi sehingga menampilkan waktu 
kriteria fisiologis yang beragam namun lebih awal, yaitu mampu mulai pada umur 57 hari setelah tanam. Apabila ditinjau dari perhitungan heat unit, maka pada umur tanaman bawang merah varietas Super Philip tersebut memiliki heat unit sebesar $947,17^{\circ} \mathrm{C}$ hari. Hal ini membuktikan bahwa mengikuti perkembangan waktu panen dengan memperhatikan kriteria fisiologisnya ternyata mendekati waktu (hari) yang tepat, karena jumlah heat unit yang dimiliki tersebut sebesar $947,17^{\circ} \mathrm{C}$ hari dan paling mendekati kebutuhan heat unit-nya sebesar $945,8^{\circ} \mathrm{C}$ hari.

Pendekatan menentukan panen tanaman budidaya menggunakan heat unit ini, nampaknya lebih memberikan kepastian waktu termasuk pada budidaya tanaman bawang merah varietas Super Philip. Konsep heat unit dimanfaatkan dan dikembangkan atas dasar bahwa tanaman setiap harinya mengumpulkan sejumlah satuan panas yang besarnya tergantung suhu rata-rata harian dan suhu dasarnya yang memberikan pengaruh terhadap setiap fase pertumbuhan tanaman. Heat unit yang dibutuhkan dimulai dari tumbuh muncul tunas sampai saat memberikan hasil. Apabila ditinjau dari unsur-unsur iklim nampaknya peranan penting suhu sangat menentukan pertumbuhan tanaman bawang merah (Yaqin dkk., 2015).

Apabila dilihat dari dukungan lokasi dan iklim pada saat budidaya tanaman bawang merah di Kota Palangka Raya, maka secara garis besar layak dan memenuhi kesesuaian syarat tumbuh karena terbukti saat budidaya tanaman bawang merah varietas Super Philip memiliki pertumbuhan yang baik dan mampu membentuk umbi dengan baik pula, meskipun saat budidaya rata-rata suhu harian yang teramati berada pada suhu harian $28^{\circ} \mathrm{C}$ dengan suhu harian yang tertinggi pernah mencapai $36,25^{\circ} \mathrm{C}$ dan suhu terendah pada $23,25^{\circ} \mathrm{C}$ (Safrudin, 2016; Nurani, 2016). Kondisi ini ternyata sesuai dengan yang disampaikan Wibowo (2001) bahwa bawang merah menyukai daerah beriklim kering, tumbuh dengan baik saat ditanam pada kisaran suhu 25$32^{\circ} \mathrm{C}$, meskipun pada suhu yang relatif rendah tanaman bawang merah masih dapat tumbuh dengan keadaan sulit membentuk umbi, dan apabila umbinya terbentuk maka hasilnya tidak sebaik umbi yang ditanam pada suhu yang sesuai.

Waktu panen tanaman bawang merah yang tepat merupakan upaya melengkapi kebutuhan bawang merah di masyarakat melalui peningkatan kualitas hasil panen. Hasil panen (produksi) yang tinggi tentunya harus selaras dengan kualitas hasil panen karena selain dengan jumlah panen yang tinggi juga membutuhkan kualitas hasil panen yang tinggi pula sebagai tindak lanjut proses pasca panen yang menjamin komoditas bawang merah tetap bermutu sampai ke pasar dan ke tangan konsumen. Kualitas hasil panen yang baik inilah salah satunya dimulai dari penentuan waktu panen yang tepat di lahan budidaya agar hasil panen tidak mudah mengalami degradasi nilai dan menekan mengalami kerusakan. Ini selaras dengan penjelasan Utama dan Antara (2013) bahwa saat panen dan pascapanen yang sesuai menjadi terasa penting dan harus dikembangkan untuk mengatasi respon yang beragam dan terjadi karena adanya perbedaan kultivar, stadia kematangan, daerah pertumbuhan, dan musim. 
Berdasarkan umur panen tanaman bawang merah varietas Super Philip pada kisaran 56-60 hari setelah tanam, dan tanaman bawang merah dapat dibudidayakan di dataran rendah (Baswarsiati, 2009), maka langkah awal menentukan waktu panen tanaman bawang merah varietas Super Philip juga bisa digambarkan pada kisaran umur tanaman tersebut sekaligus mendapatkan hitungan satuan panas (heat unit) yang dilakukan di masingmasing lingkungan tumbuh lokasi budidayanya. Untuk itu perlu mendapatkan gambaran besaran heat unit yang dibutuhkan tanaman bawang merah di suatu lokasi budidaya sekaligus menggambarkan kemampuan produksi umbinya atas kesesuaian lokasi dan peran suhu harian di sekitarnya yang ditunjukkan melalui besaran heat unit.

Safrudin (2016) menjelaskan bahwa budidaya tanaman bawang merah varietas Super Philip akibat pemberian bokashi pupuk kandang kotoran ayam di tanah gambut yang dipanen sesuai heat unit sebesar $947,14^{\circ} \mathrm{C}$ hari dan dimulai panen pada umur 57 hari setelah tanam ternyata tetap mampu menghasilkan jumlah umbi mencapai 11,00 umbi per rumpun. Sedangkan Nurani (2016) juga melaporkan bahwa budidaya tanaman bawang merah varietas Super Philip akibat pemberian pupuk kandang kotoran ayam di tanah gambut yang dipanen sesuai heat unit sebesar $978,09^{\circ} \mathrm{C}$ hari dan dimulai panen pada umur 59 hari setelah tanam juga mampu menghasilkan jumlah umbi rata-rata mencapai 10,30 umbi per rumpun.

Berdasarkan Tabel 2, menunjukkan bahwa ada kesesuaian waktu panen secara kriteria fisiologis dengan perhitungan heat unit pada tanaman bawang merah varietas Super Philip karena mendekati jumlah heat unit yang dibutuhkan untuk waktu panen yaitu sebesar $945,8^{\circ} \mathrm{C}$ hari dan yang mendekati kebutuhan tersebut adalah pada umur 57 hari dengan heat unit sebesar $947,14^{\circ} \mathrm{C}$ hari. Sedangkan apabila diperhatikan pada umur 56 hari setelah tanam, maka jumlah heat unit yang terkumpul baru sebesar $931,29^{\circ} \mathrm{C}$ hari, artinya belum cukup waktunya panen karena menurut Yaqin dkk. (2015) bahwa tanaman bawang merah varietas Super Philip membutuhkan jumlah heat unit sebesar $945,8^{\circ} \mathrm{C}$ hari.

Selain memenuhi jumlah satuan panas untuk panen, kondisi kriteria fisiologis berhubungan dengan waktu panen yang tepat untuk tanaman bawang merah pada umur 57 hari setelah tanam tersebut sesuai juga dengan yang dijelaskan Safrudin (2016) bahwa pengamatan kriteria fisiologis layak panen pada budidaya tanaman bawang merah varietas Super Philip terlihat di lapangan pada umur mulai 57 hari setelah tanam yang telah menunjukkan kesesuaian untuk dipanen karena kondisi daunnya yang sudah mulai layu, daunnya telah menguning mencapai $80 \%$, pangkal batangnya mengeras, sebagian umbinya telah keluar di atas tanah, dan lapisan umbi yang muncul ke permukaan tanah terlihat telah berwarna merah.

\section{KESIMPULAN DAN SARAN}

\section{Kesimpulan}

Penelitian waktu panen yang tepat pada tanaman bawang merah varietas Super Philip yang berbasis perhitungan heat unit ini menghasilkan kesimpulan, bahwa : 
a. Waktu panen tanaman bawang merah varietas Super Philip sesuai perhitungan heat unit adalah sebesar $945,8^{\circ} \mathrm{C}$ hari dan jumlah heat unit yang paling mendekati saat budidaya sebesar $947,17^{\circ} \mathrm{C}$ hari pada umur $57 \mathrm{HST}$.

b. Waktu panen tanaman bawang merah varietas Super Philip sesuai kriteria panen fisiologis akibat perlakuan bokashi pupuk kandang kotoran ayam (BK) pada umur 57 HST adalah relatif tepat dan sesuai karena memiliki heat unit sebesar $947,17^{\circ} \mathrm{C}$ hari.

c. Waktu panen tanaman bawang merah varietas Super Philip sesuai kriteria panen fisiologis akibat perlakuan pupuk kandang kotoran ayam (PK) pada umur 59 HST adalah relatif terlambat karena telah memiliki heat unit sebesar $978,09^{\circ} \mathrm{C}$ hari.

\section{Saran}

Hasil penelitian waktu panen tanaman bawang merah berbasis perhitungan heat unit ini menghasilkan saran bahwa diperlukan penelitian lanjutan untuk penentuan waktu panen tanaman bawang merah varietas Super Philip berdasarkan penghitungan heat unit pada budidaya di beberapa musim tanam di tanah gambut.

\section{UCAPAN TERIMA KASIH}

Ucapan terima kasih disampaikan kepada Agus Safrudin dan Hairunnisa Nurani selaku mahasiswa Program Studi Agroteknologi Fakultas Pertanian dan Kehutanan Universitas Muhammadiyah Palangkaraya yang terlibat bersama dalam penelitian budidaya tanaman bawang merah di tanah gambut menggunakan pupuk organik. Terimakasih juga kepada Universitas Muhammadiyah Palangkaraya yang memfasilitasi penelitian ini pada Tahun 2016.

\section{DAFTAR PUSTAKA}

Baswarsiati, 2009. https://baswarsiati.wordpress.com/2009/04/ 30/tiga-varietas-unggul-bawang-merahhasil-kajian-bptp-jawa-timur/. Diakses pada tanggal 22 Januari 2016.

BPS, 2015. Statistik Hortikultura Kalimantan Tengah. Badan Pusat Statistik Kalimantan Tengah.

Kamillah, 2006. Penaksiran Waktu Berbunga dan Saat Panen Tanaman Kedelai Varietas Wilis dengan Jumlah Panas (Heat-Sum). Lamina, Media Publikasi IImiah, ISSN : 0216-6089, Volume 2, Nomor 2, Desember 2006, 55-62.

Mattjik, A. A. dan I.M. Sumertajaya, 2002. Perancangan Percobaan Dengan Aplikasi SAS dan Minitab. Jilid I Edisi Ke-dua. IPB PRESS. Bogor.

Nurani, H., 2016. Pengaruh Pupuk Kandang Kotoran Ayam dan Pupuk Multi KP terhadap Umur Panen dan Hasil Bawang Merah (Allium ascalonicum L.) pada Tanah Gambut. Skripsi (tidak dipublikasikan). Fakultas Pertanian dan Kehutanan Universitas Muhammadiyah Palangkaraya. Palangka Raya.

Polii, M.G.M., 2003. Penentuan umur berbuah tanaman cabe merah (Capsicum annum var.longum Sendt) pada tiga tinggi tempat yang berbeda menggunakan metode satuan panas. Eugenia 9(2):104-108.

Safrudin, A., 2016. Pemberian Pupuk Bokashi Kotoran ayam dan Kapur Dolomit terhadap Pertumbuhan dan Hasil Tanaman Bawang Merah (Allium ascalonicum) pada Tanah Gambut. Skripsi (tidak dipublikasikan). Fakultas Pertanian dan Kehutanan Universitas Muhammadiyah Palangkaraya. Palangka Raya.

Soelistyono, R., 2010. Penggunaan Suhu Udara Untuk Menentukan Suhu Dasar Beberapa Jenis Tanaman. Fakultas Pertanian Universitas Brawijaya. Malang. 
Utama, I. M. S. dan N. S. Antara, 2013. Pasca Panen Tanaman Tropika : Buah dan Sayur. Tropical Plant Curriculum Project. Udayana University. Denpasar, Bali.

Wahyono, E.H., H.R. Sadjudin, B.R. Soetrisno, N. Sudarno, Jueni, E. Hidayat, B. Lesmana, A. Arika J, Bonaji, Erwindo, Suhadi dan Sutarto. 2013. Pertanian Alami : Budidaya Sayuran Alami. Konsorsium YABI-WCSYAPEKA. Bogor.

Wibowo, S. 2001. Budi Daya Bawang Putih, Merah dan Bombay. Penebar Swadaya. Jakarta

Yaqin, N.A., N. Azizah dan R. Soelistyono., 2015. Peramalan Waktu Panen Tiga Varietas Tanaman Bawang Merah (Allium ascalonicum. L) Berbasis Heat Unit pada Berbagai Kerapatan Tanaman, Jurnal Produksi Tanaman, Volume 3, Nomor 5, Juli 2015, hlm. $433-441$. 